\title{
Seismic Response Analysis of Masonry Minaret and Possible Strengthening by Fiber Reinforced Cementitious Matrix (FRCM) Materials
}

\author{
Ahmet Murat Turk \\ Civil Engineering Department, Istanbul Kultur University, Atakoy Campus, Bakirkoy, 34156 Istanbul, Turkey \\ Correspondence should be addressed to Ahmet Murat Turk; murat.turk@iku.edu.tr \\ Received 15 February 2013; Revised 16 May 2013; Accepted 20 May 2013 \\ Academic Editor: Jianqiao Ye
}

Copyright (C) 2013 Ahmet Murat Turk. This is an open access article distributed under the Creative Commons Attribution License, which permits unrestricted use, distribution, and reproduction in any medium, provided the original work is properly cited.

\begin{abstract}
This paper presents the analytical study on the dynamic response of a natural stone block masonry minaret of a historical mosque located in Istanbul, Turkey. A three-dimensional finite element model of the whole minaret, adjusted with former in situ ambient vibration test results, was used in order to get probable lateral displacements, stresses, and understanding of failure modes under seismic loading. Particularly, FEM has been used to evaluate the seismic safety of the minaret in present-day condition and after the application of a proposed strengthening method. In this method, by utilizing the fiber reinforced cementitious matrix (FRCM) material, the critical cross-sections were jacketed. The appearing damage for the bare minaret obtained from FEM analyses was located at the boot and transition part of the minaret. After FRCM material was wrapped around these critical cross-sections, the analytical results indicated that such method appears effective in terms of the seismic response. It also appears less invasive in terms of the conservation of historical heritage like minarets without causing aesthetic conflict on the existing structure when compared to other available techniques.
\end{abstract}

\section{Introduction}

Turkey has an enormous amount of existing historical structures inventory and it is located in one of the most seismically active regions of the world. The seismic protection of historical heritages has been always challenging for structural engineering profession to analyse, as well as seismic strengthening of these structures due to highly complex behaviour of the materials. The problem becomes more complicated when the dynamic behavior is also engaged. During the last two decades, major earthquakes like Erzincan (1992), Dinar (1995), Ceyhan (1998), Kocaeli and Duzce (1999), Elazig (2010), and Simav (2011) caused significant casualties and extensive structural damage in Turkey. The number of damaged buildings after the earthquakes exceeds 25,000. During Kocaeli (17 August 1999) and Duzce (12 November 1999) earthquakes, 15000 people were killed and more than 20000 were injured. Beside the failure and damage for building structures, historical structures like mosques and minarets have experienced different levels of damages. On the other hand, historical records have informed the destructive effects of past major earthquakes occurred near Istanbul and old cities around the Anatolia. In Istanbul, after the 1894 earthquake, 69 minarets were reported as damaged within historical Peninsula, 30 of which were totally collapsed [1]. Since then, Istanbul has not experienced such large earthquake produced by the same fault system which is a part of North Anatolian Fault System and it is located under the Marmara Sea which surrounds the southern coasts of the city of Istanbul.

Mosques and minarets can be presumed as the symbols of Islamic religious architecture. Generally a mosque is combined of a wide space roofed over by a main dome and subdomes, which are carried by arches, walls, and columns. Every mosque has minimum one minaret which is essentially a cylinder-shaped tower-like slender structure. Minarets can be built either as attached to side walls or to the roof of the mosque. The number of the minarets changes due to the importance of the mosque. The height of a minaret is usually between $25 \mathrm{~m}$ and $70 \mathrm{~m}$ depending on its number of 
balconies [2]. The top of the minaret is covered by a conical cap, which is made of a light material like wooden frame covered with lead sheets.

Due to progress in the in situ testing of structures and computational methods, the studies have shown some significant contributions about the mechanical behaviour of the historic minarets. It is important to understand the dynamic behaviour of historical masonry minarets to improve the life safety and to preserve and strengthen the historical monumental structures against earthquakes. Previously, an ambient vibration study on the Dolmabahce Mosque minarets was carried out by a research team from Istanbul Technical University and microtremor data had been recorded. The study was concluded with the model analysis results of the finite element model with the proposed mechanical properties of the mentioned structural system [3]. A new retrofit method by using FRP wrapping for the same minaret was proposed in previous analytical studies [4-6]. Main vulnerabilities and damages to 64 masonry and reinforced concrete minarets after the 1999 Kocaeli and Duzce Earthquakes were discussed and the seismic response of reinforced concrete minarets was investigated in other studies [7-9]. In addition, the behaviour of reinforced and unreinforced masonry minarets subjected to dynamic earthquake loading was analysed and evaluated $[10,11]$. In two other studies, dynamic behaviours of typical minarets made of natural block stone were investigated by using finite element method $[12,13]$. The behaviour of a masonry chimney with severe damage and strengthened keeping the existing view by employing numerical analysis was examined [14]. In another study, the test results of structural behaviour of dry joint masonry were presented. Under the in-plane combined compressive and shear loading, the structural behavior, and ultimate capacity, observed failure mechanisms were studied [15].

In addition, for the seismic strengthening of the existing historical minarets, structural level intervention is needed rather than member level such as jacketing of walls, addition of internal walls, addition of internal steel bracings, external steel framing, posttensioning, and base isolation $[6,9,11]$. Due to the strict rules of historic preservation of monumental structures, local conservation committees usually request the more structurally effective but least intrusive techniques from the point of protection of the original aesthetic view and original architectural functions [16]. Different forms of wrapping of main body of minaret by reinforced concrete, steel sheets, and fiber reinforced polymer (FRP) wraps can be used efficiently in order to increase lateral strength $[5,6,12]$. Fiber reinforced polymer (FRP) materials are currently extensively utilised for retrofit and repair of concrete and masonry. Main advantages of FRP materials can be given such as the increase in the strength without adding extra weight, high durability, and quick and easy installation. On the other hand, low fire resistance, high sensitivity to ultraviolet radiation when exposed to open air, high toxicity, low vapour diffusion, and relatively short shelf life can be specified as disadvantages of the system. Especially for the historical masonry structures, these disadvantages may be detrimental on the long run. To dismantle the strengthened cross-sections should be easy and less detrimental if a less intrusive and/or more innovative technique is offered in the future [16]. FRP wrapping by epoxy on the masonry seems troublesome process when dismantling is necessary which needs extensive research.

Presently, the application of fiber-reinforced cementitious matrix (FRCM) materials may overcome such disadvantages by its resistance to high temperatures and radiation and high vapour diffusion ability [17-19]. FRCM materials are combined of a fiber mesh which may be either polyparaphenylene benzobisoxazole (PBO) fiber mesh or carbon fiber mesh and a cementitious mortar matrix which is stabilized by dry organic fibers. $\mathrm{PBO}$ fibers have the uniaxial tensile strength of $6000 \mathrm{MPa}$ which is $50 \%$ higher than the carbon fiber's strength $[19,20]$. The mechanical effectiveness of FRCM is intensely impacted by the capability of the matrix to saturate dry fiber mesh, bonding between the matrix and fibers and bonding the matrix and the strengthened/repaired surface. Ongoing research has revealed that the mechanical efficiency of the material on the concrete and masonry surfaces and the use of cementitious matrix instead of epoxy bring important advantages like easy preparation on the site, less timeconsuming preparation process, and installation of mortar even on wet substratum either concrete or masonry where the surface must be free from dust, humidity, and oil for epoxy bonding. In situ application of epoxy requires cautious process due to the toxic nature of the material.

Similarly, FRCM materials may be effective in order to protect the structural safety and serviceability of the minaret as well by following the approaches of architectural preservation and saving the integrity and strength before and after earthquakes. Ease of application and the less invasive nature of the technique with respect to other strengthening alternatives inspired the author to investigate the behaviour of minaret strengthened with FRCM materials which opens a gateway to conservation authorities of historical heritage like minarets without causing aesthetic conflict on the existing structure when compared to other available techniques.

In this study, an existing historical minaret in Istanbul was taken as case structure. As being different from the previous analytical studies [4-6, 12], FRCM material was utilised as confinement material around the critical cross-sections of the minaret. By performing linear dynamic analyses, the effectiveness of seismic strengthening of the minaret by FRCM material was investigated.

\section{Case Minaret Structure and Material Properties}

In Figure 1, two minarets of Dolmabahce Mosque in Istanbul, of which west minaret of this mosque was taken as a case in this paper, can be seen. The dimensions of the minaret were given in the Figure 2 in details [3]. Dolmabahce Mosque was built near the Dolmabahce Palace of Ottoman Empire with neoclassical and baroque architectural style in 1855 on the coast of Bosphorus, Istanbul. The mosque is located on the shore of the Bosphorus Strait, in European side, on the south of Dolmabahce Palace. Although both minarets look 


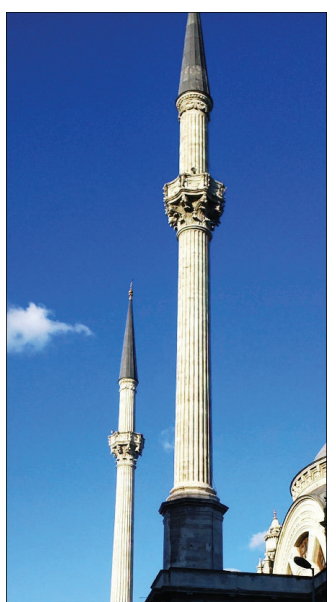

FIgURE 1: View of Dolmabahce Mosque minarets (taken by author).

identically the same, the west minaret has its original form although the other one was restored lately. This study is mainly focused on the west side minaret so that the result can enlighten the real mechanical behaviour of the structural system (Figures 1 and 2).

The minaret footing is made by using very thick stone blocks and connected with the heavy exterior wall of the mosque. Minaret is a tower-like slender cantilever structure. The lower part, from bottom to the gallery, is constituted by the wall, the stairs, and the core. The thickness of the masonry wall in this part decreases along the length. Inside of the upper part from gallery to the top of minaret is empty which has no use. The wall thickness of cylindrical upper part is constant all along the length. Balconies are mostly used for prayers which create mass concentration along the minaret's height and affect its dynamic structural response [3]. The diameter and thickness of the upper part's cross-section is smaller than the main body and the boot. The conical cap part of the minaret was constructed with mounted timber frame covered with lead sheets (Figures 1 and 2).

Previous studies about the different types of masonry structures around Istanbul have formed an important inventory for the future studies [2]. During the construction of the minaret, limestone (also named as Kufeki stone or Maktarali limestone) had been extensively used in all of the buildings in Dolmabahce Mosque. Lately, during the renovation process of the mosque, numerous material tests were performed on the limestone specimens collected from the rubbles of the old historical structures and ancient queries near Istanbul. The report of Istanbul Technical University on the limestone samples was published in 2000, and typical mechanical properties of the Kufeki stone are given in Table 1 [3]. Kufeki stone had been used by Mimar Sinan, famous architect of the Ottoman Empire who had lived between 1489 and 1588, for the construction of his all historical structures around Istanbul. The geological background of the stone belongs to Miocene formation and contains $\mathrm{CaCO}_{3}(93 \%-100 \%)$. It is a natural composite material due to its matrix structure of accumulated and metamorphosed sea shells [21-24].

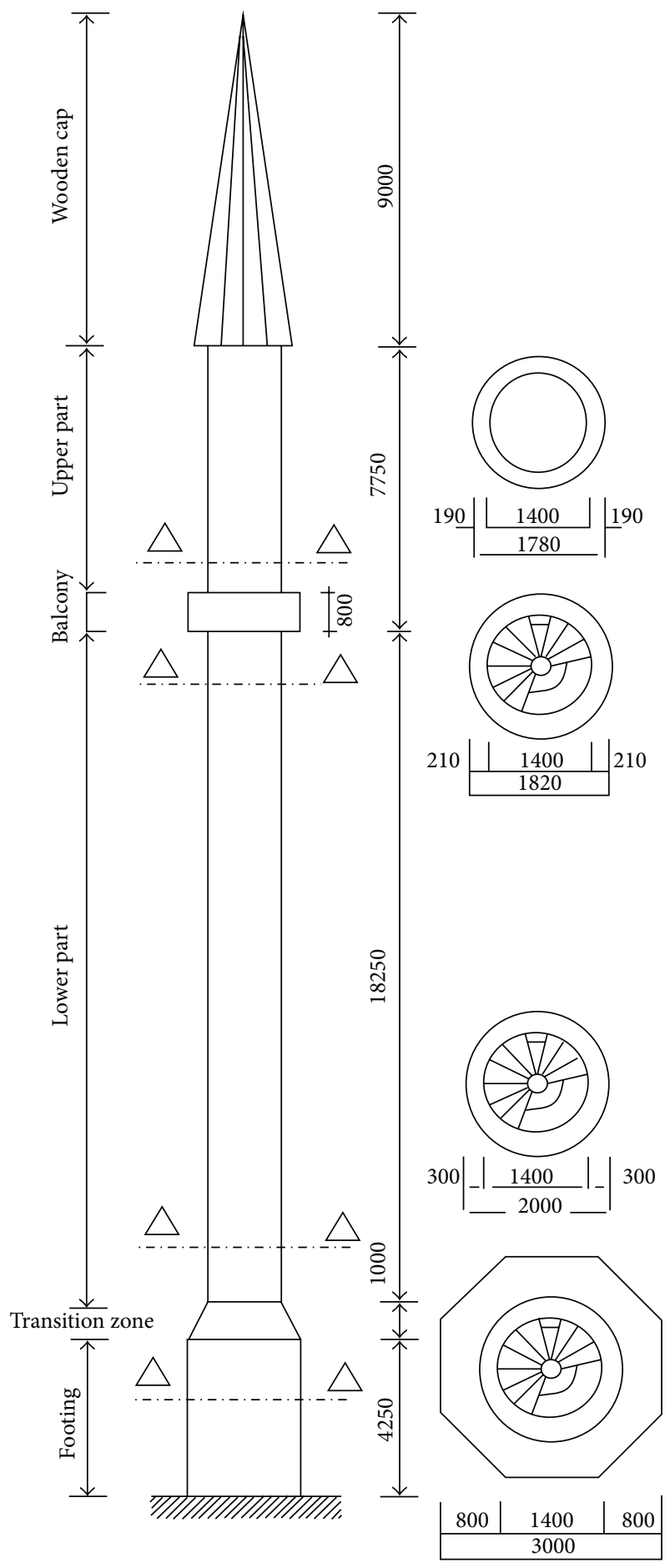

FIGURE 2: Geometrical and cross-sectional properties of the minaret (all dimensions are in $\mathrm{mm}$ ) [3].

The modulus of elasticity of uncracked limestone was taken as $8856 \mathrm{MPa}$ in this study. The ratio of modulus of elasticity, $E$, to the uniaxial compressive strength $\left(f_{c}\right)$ was assumed as 720 where $f_{c}=12.3 \mathrm{MPa}$ (minimum compressive strength of Kufeki stone given in Table 1). This ratio of 720 was proposed in a previous experimental study where the 
TABLE 1: Mechanical properties of Kufeki limestone used in the analysis [3].

\begin{tabular}{lccc}
\hline Physical properties & Max. & Min. & Average \\
\hline Density $\left(\mathrm{kg} / \mathrm{m}^{3}\right)$ & 2500 & 2300 & 2390 \\
Uniaxial compressive strength $(\mathrm{MPa})$ & 19.2 & 12.3 & 16.7 \\
Uniaxial tensile strength $(\mathrm{MPa})$ & 0.95 & 0.88 & 0.9 \\
\hline
\end{tabular}

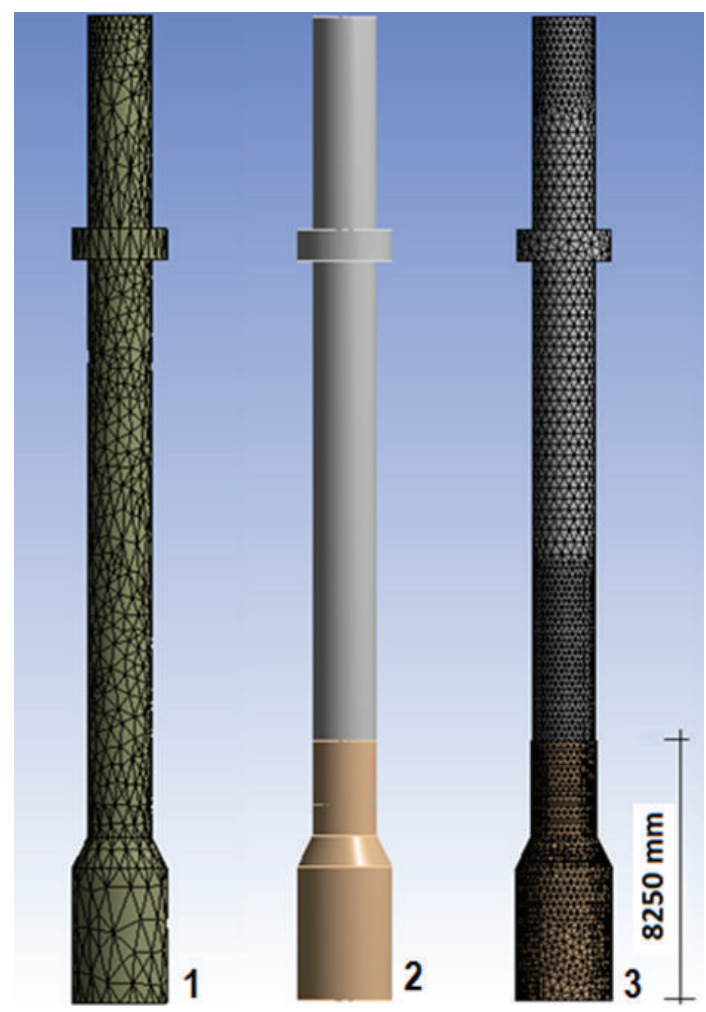

FIGURE 3: 3D finite element ANSYS models of the meshed bare minaret (1), FRCM strengthened minaret (2), and meshed model of FRCM strengthened minaret (3).

mechanical properties of Kufeki limestone had been extensively tested and the typical uniaxial compressive strength to uniaxial tensile strength ratio is determined between 11 and 12 [21-24]. The Poisson ratio and unit weight of the stone were taken as 0.24 and $2300 \mathrm{~kg} / \mathrm{m}^{3}$, respectively.

FRCM material was supposed to be used as seismic strengthening material for masonry in order to increase the lateral strength. The boot, transition zone and lower part of body of minaret was assumed to be wrapped by using FRCM material with PBO fiber-net until the height of $8.25 \mathrm{~m}$ from the bottom (Figure 3). The surface of the minaret was covered with concrete mortar to get a rounded surface with the aim of better confinement effect in the analytical model. For the analytical study, the mechanical properties of the FRCM material were taken as follows: tensile strength of PBO fiber net was assumed as $5200 \mathrm{MPa}$ in both directions (longitudinal and transversal), and elastic modulus and failure strain were taken as $270000 \mathrm{MPa}$ and 0.02 , respectively. Total thickness of the FRCM material was chosen as $50 \mathrm{~mm}$ with 4 plies of
PBO fiber net. Thickness of a single ply of PBO net is 0.046 and $0.011 \mathrm{~mm}$ for longitudinal and transversal direction [19, 20]. Cementitious matrix material properties were chosen as tensile strength of $2.5 \mathrm{MPa}$, compressive strength of $30 \mathrm{MPa}$ $[19,20]$. Before the analysis, full bond between all surfaces and full anchorage of the FRCM wrap to the foundation were assumed.

\section{Dynamic Analysis of the Minaret}

The three-dimensional finite element models have been generated in order to study the dynamic behaviour of the minaret which is shown in Figure 3. Three-dimensional finite element models of the minaret were created by using the ANSYS software [25]. This software is available and extensively used for linear, nonlinear, static, and dynamic analyses of the structures. In this study, for the three-dimensional finite element model of the minaret, SOLID 186 elements were utilised to model the dynamic behaviour of minaret model with and without FRCM reinforcement. This ANSYS element, structural solid element, is defined by 20 nodes having three degrees of freedom per node: translations in the nodal $x, y$, and $z$ directions which are also capable of showing quadratic displacement behaviour. In addition, SOLID186 elements have calculation capability of plasticity, elasticity, creep, stress stiffening, large deflection, and large strains. During the analysis, 32563 and 38329 SOLID186 elements are assembled for minaret model before and after FRCM strengthening. In the Figure 3, 3D meshed volumes are shown before and after strengthening. The 3D model includes the spiral stairs made of stone and linked to the minaret outer walls up to balcony.

Masonry is an anisotropic composite material which has different directional mechanical properties due to the presence of mortar joints between masonry units and these joints act as potential planes of weakness. During the FEM modelling in this study, a material model approach was assumed with a homogeneous isotropic continuum by neglecting the difference between mortar joints and limestone units. This simplification usually was preferred due to large dimensions of the minaret structure in order to have reduced run time, to get reasonable automated mesh generation, and to separate the safe and unsafe regions within the limitation of an acceptable efficiency and accuracy. This means that homogenization is much more design oriented where the interaction between stone units and mortar is not much cared. In addition, for the case minaret, additional data required for micro or macromodelling is not available in the literature. Detailed mechanical properties of mortar and the mechanical tests on wall samples in all directions (either in situ or in laboratory) are necessary to utilise the detailed modelling techniques.

Wooden cap was neglected during the study due to its light gage structure different from masonry but the dead load of the wooden cap (top part of minaret) was uniformly distributed on the top of minaret wall. The base of the minaret was considered as fixed support during the analysis. As it can be seen from Figure 1, because of the base part of the minaret 


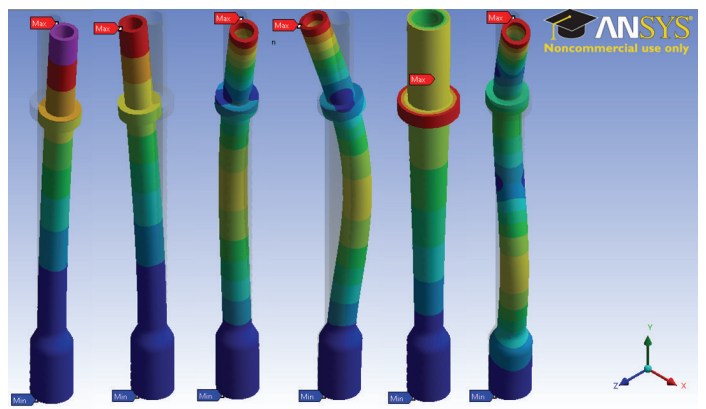

Figure 4: Mode shapes of the bare minaret model (Modes 1 to 6 are lined from left to right).

TABLE 2: The first six calculated natural periods and frequencies before seismic strengthening.

\begin{tabular}{lcccccc}
\hline Modes & 1st & 2nd & 3rd & 4th & 5th & Torsional \\
\hline Direction & Lateral & Lateral & Lateral & Lateral & Lateral \\
Period (sec) & 1.229 & 1.229 & 0.191 & 0.191 & 0.100 & 0.077 \\
Frequency $(\mathrm{Hz})$ & 0.813 & 0.814 & 5.224 & 5.225 & 9.910 & 12.888 \\
\hline
\end{tabular}

TABLE 3: The first six calculated natural periods and frequencies after seismic strengthening with FRCM.

\begin{tabular}{lcccccc}
\hline Modes & 1st & 2nd & 3rd & 4th & 5th \\
\hline Direction & Lateral & Lateral & Lateral & Lateral & Torsional & Lateral \\
Period $(\mathrm{sec})$ & 0.930 & 0.928 & 0.149 & 0.148 & 0.087 & 0.061 \\
Frequency $(\mathrm{Hz})$ & 1.075 & 1.077 & 6.709 & 6.743 & 11.418 & 16.405 \\
\hline
\end{tabular}

constructed onto the very thick external walls of the mosque, possible rotations of external walls that may take place during earthquake were disregarded. No soil-structure interaction or base rotations have been taken into consideration.

In the structural model, linear elastic material behaviour was assumed and the stiffness degradation, softening, and hardening of material were neglected. The second order effect (P-delta) was ignored in the analysis owing to the low level of vertical loading (dead loads only). The minaret is located in a highly seismic region with weak soil layers located adjacent seashore and constructed on a hydraulic fill. According to Turkish Seismic Code 2007, the location is presumed as 1st seismic zone, and soil class is taken as Z4 soil class according to TSC 2007 [26] and Type D soil class according to Eurocode 8 [27]. In addition, 5\% damping ratio was assumed for dynamic analysis of the minaret structure. In-situ micro tremor tests performed on an instrumented old Mexican masonry building showed that viscous damping was measured between 6 and 12\% for the earlier recorded events [28]. In a recent study about minarets, ambient vibration test results performed on Istanbul minarets gave $0.5 \%-1 \%$ damping for low amplitude motion [13]. No real-time test data is available on the response of Turkish minarets under seismic loads.

Dynamic linear analyses of the minaret models show that for most cases very high stresses are expected at the transition zone to cause the failure of the minaret similar to the previous failures/collapses during past events. In previous studies, postearthquake investigation of minaret failures and results of analysis show that the most of masonry minarets failed at the bottom part of the cylindrical body, just above the transition zone [4-7, 11-13].

Fiber reinforced cementitious matrix (FRCM) use in strengthening of historical structures against earthquakes has gained importance recently. Due to the aforementioned advantages of FRCM materials especially for historical structures, the potential use of FRCM jacketing around minaret structure was investigated through providing extra flexural and shear capacity. Previous studies and collapses have shown that the boot, lower part of minaret just below and over the transition zone appears as weak zone in terms of normal and shear stresses. FRCM wrapping around these critical zones seems easy and viable procedure in terms of retrofit. The full anchorage of FRCM material on the stone masonry should be supplied either by using dowels/anchors while jacketing or by connecting FRCM to foundation of the structure.

The measured dynamic properties of the minaret which was previously subjected to a series of in situ ambient vibration tests were taken as basis and used with the purpose of calibrating the three-dimensional finite element analysis of the minaret [3]. The first six natural periods of the minaret model (calculated from the modal analysis) and mode shapes were presented in Tables 2 and 3 and in Figures 4 and 5. The fundamental period of minaret model calculated by modal analysis was found almost the same with the ambient vibration measurements results [3]. The first four modes' contribution to the response is quite significant in which the first and second modes' participation is 34\%. The higher 


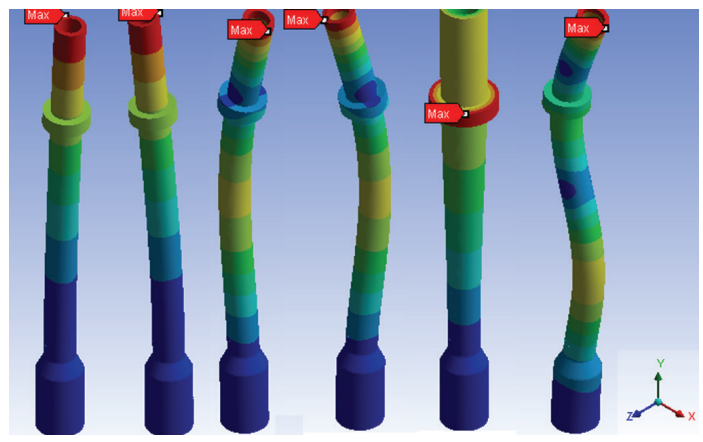

FIGURE 5: Mode shapes of the minaret model strengthened with FRCM wrapping (Modes 1 to 6 are lined from left to right).

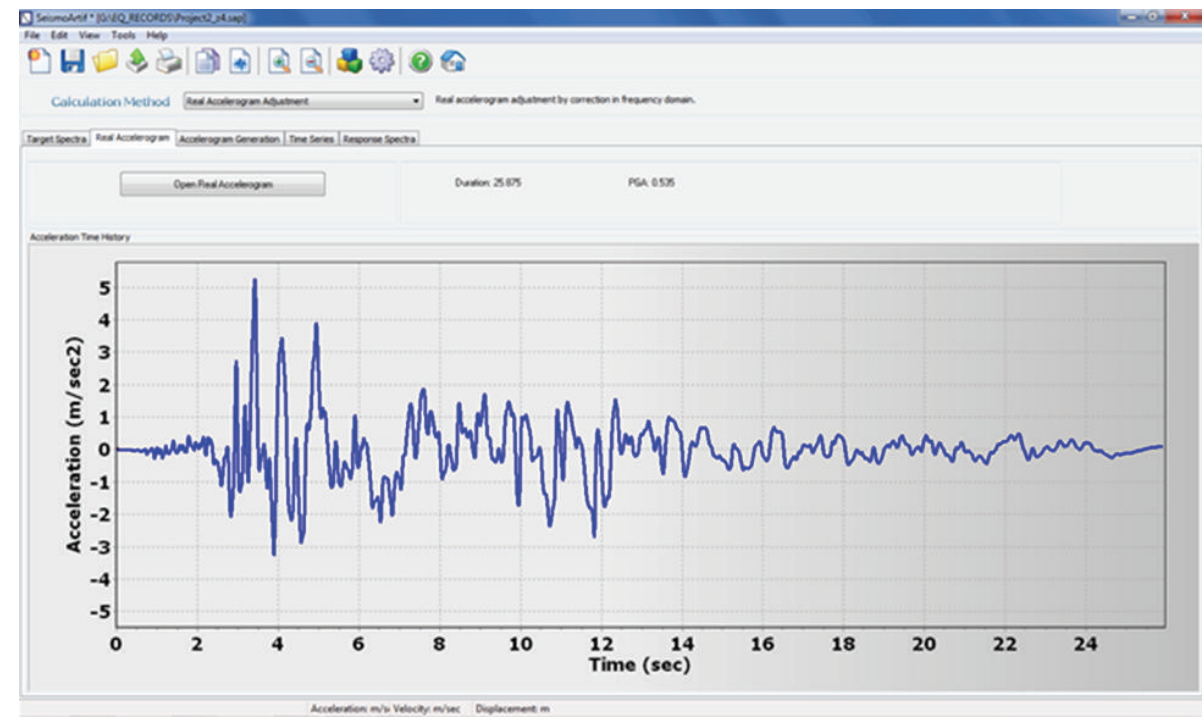

FIgURE 6: Real accelerogram recorded during Duzce 99 earthquake at Duzce Station [30].

modes (5th and 6th modes) have nearly no effect on the response of the minaret. In ITU study, microtremor tests had been performed on the minaret structure and by using ambient vibrations, fundamental frequency of the minaret was measured as $0.88 \mathrm{~Hz}$ and first period calculated as $1.136 \mathrm{sec}$ [3]. The calculated first period for minaret model in this study is $1.229 \mathrm{sec}$. (Table 2). Also, 7\% difference can be assumed as negligible for practical design purposes for the presumed structural parameters.

The calculated first and second natural periods before and after FRCM strengthening show almost 30\% decrease although the thickness of FRCM with respect to the wall thickness is incomparably small.

Due to the proper match of natural periods of minaret structure between measured and calculated values, previously-assumed mechanical properties were also utilised for time history analysis. Two different time history analyses were performed by using artificially generated accelerograms. Instead of using real ground motion records which can be defined as far-field earthquakes for the case minaret, the real accelerograms were adjusted and scaled with available software of SeismoArtif to get the artificial accelerograms based on the target spectra given in Turkish Seismic Code 2007 for the soil class Z4 [26]. SeismoArtif is a software which is capable of generating artificial accelerograms matched to a specific target response spectrum using different calculation methods and varied assumptions [29]. One of the accelerograms is produced by scaling the ground motion record of Duzce Station (parallel to fault) obtained during Duzce EQ (Figure 6).

The main characteristics of the chosen ground motion on soft soil condition are epicentral distance: $1.61(\mathrm{~km})$, hypocentral distance: $14.09 \mathrm{~km}$, Joyner-Boore distance: $0.00 \mathrm{~km}$, closest distance: $6.58 \mathrm{~km}$, PGA: $0.52 \mathrm{~g}, \mathrm{PGV}: 70.7700 \mathrm{~cm} / \mathrm{sec}$, PGD: $47.3 \mathrm{~cm}$, and $\mathrm{V}_{\mathrm{s} 30}: 276.00 \mathrm{~m} / \mathrm{s}$. All original records are obtained from the PEER Ground Motion Database [30]. Besides, by employing the same software, a single synthetic accelerogram was generated by assuming the parameters of moment magnitude of 8 , for near field earthquake and NEHRP class $\mathrm{D}\left(\mathrm{V}_{\mathrm{s} 30}=255 \mathrm{~m} / \mathrm{s}\right)$ by assuming linear site effects with the maximum peak ground acceleration of $0.6 \mathrm{~g}$ and absolute acceleration response spectra for Z4 soil conditions according to TSC 2007 [26]. Both artificial accelerograms were scaled to a peak ground acceleration of $0.6 \mathrm{~g}$. To determine this maximum acceleration, seismic design code of coastal and harbour structures, railways, and airport 


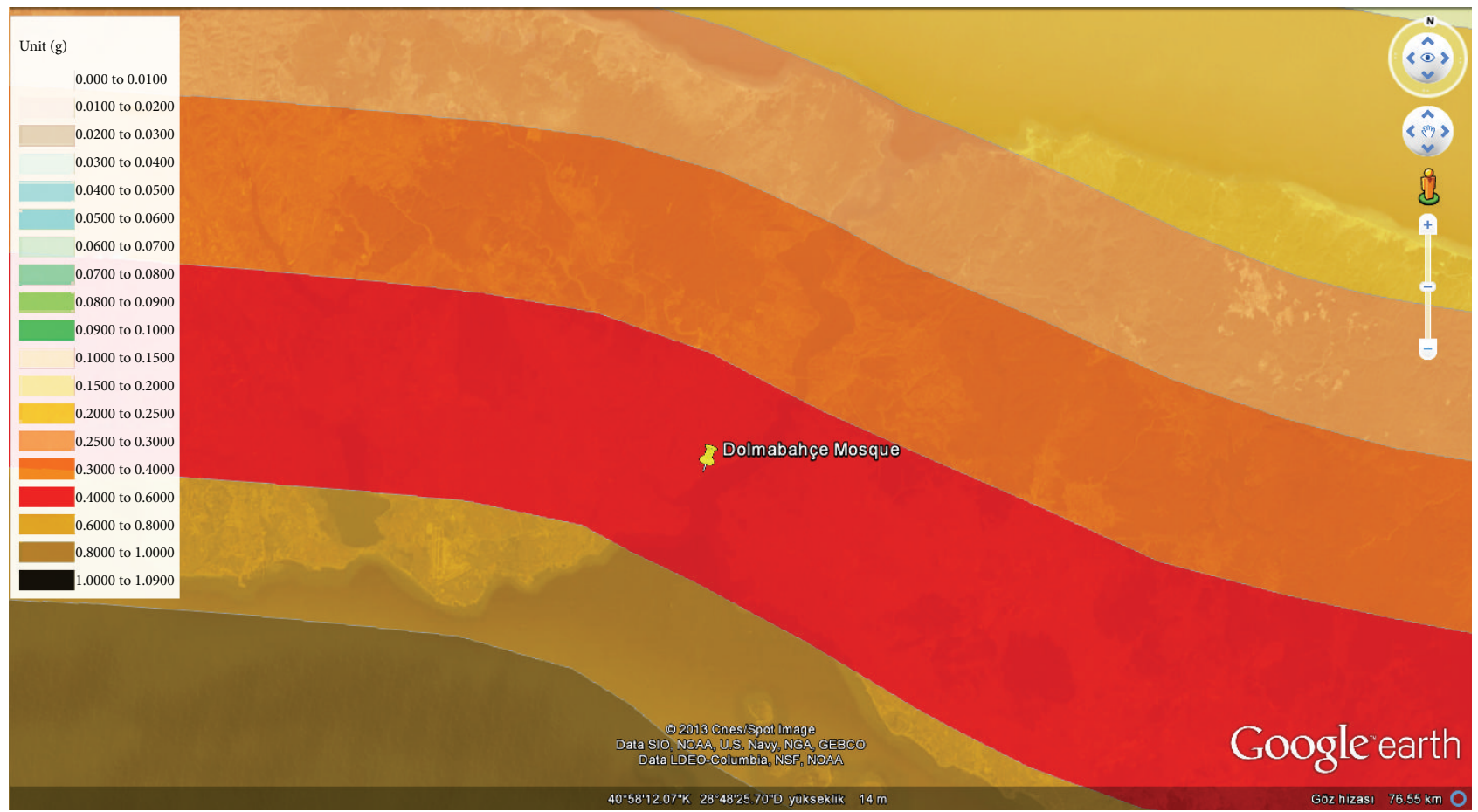

FIGURE 7: Maximum peak ground acceleration map for 475 years return period (10\% exceedance in 50 years) [31-33].

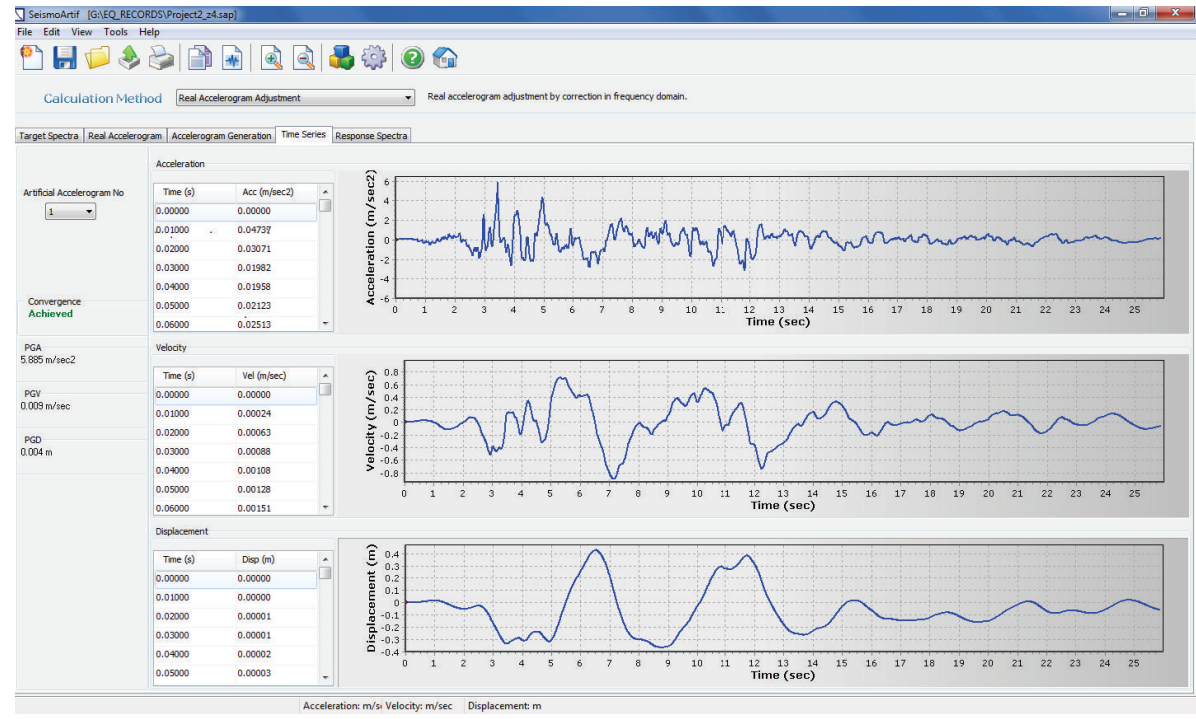

FIGURE 8: Calculated time series charts for the scaled Duzce EQ accelerogram.

facilities in Turkey is followed [31]. In the code, maximum peak ground acceleration value for the code earthquake with the return period of 475 years ( $10 \%$ exceedance probability in 50 years) is given $0.6 \mathrm{~g}$ for the location the minaret structure (Figure 7).

For the scaled and adjusted accelerograms, time series of acceleration, velocity, and displacement for the two different artificial accelerograms can be seen in Figures 8 and 9. In addition, in Figure 10, absolute acceleration response spectra for Z4 soil conditions according to TSC 2007 [26] and response spectra of two different generated artificial spectral accelerations are shown. The spectral values for artificially generated earthquakes based on real earthquake data were given for soft soil conditions during 1999 earthquakes. The figure also provides a comparison between the linear elastic acceleration response spectra calculated for soft soil conditions and those of the TSC 2007 with 5\% damping for the highest seismicity in Turkey, respectively. The elastic spectral demand obtained from TSC 2007 is comparable with the demands calculated using the adjusted and synthetic records. 


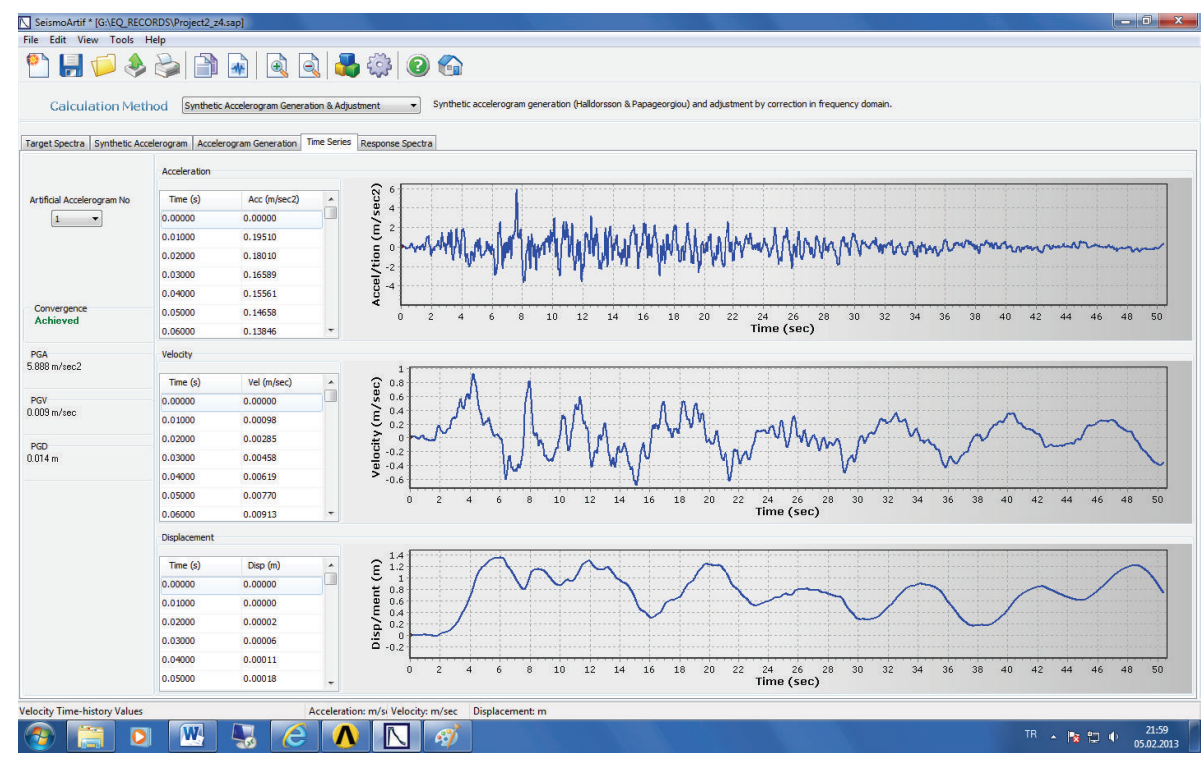

FIGURE 9: Calculated time series charts for the synthetic accelerogram.

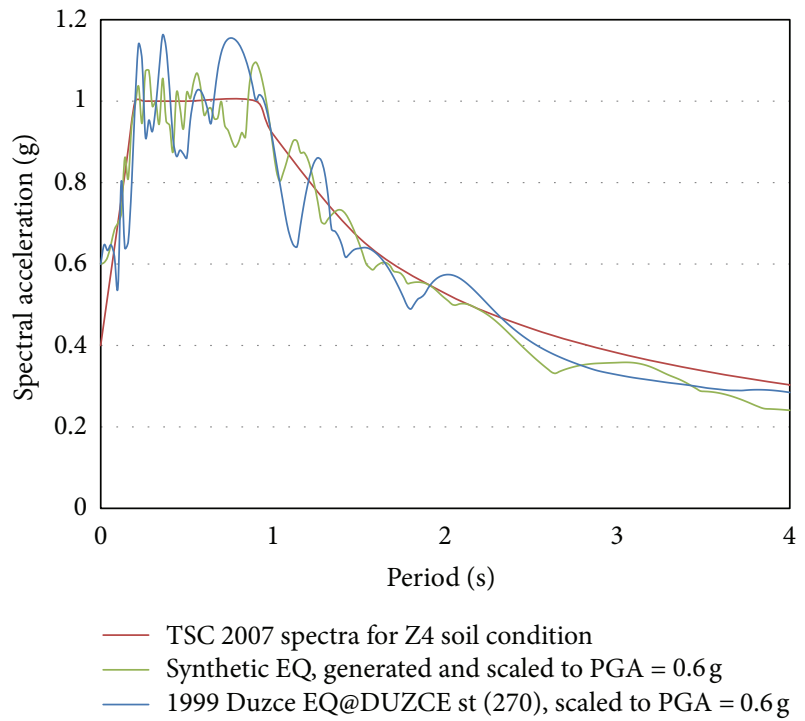

FIGURE 10: Absolute acceleration response spectra for Z4 soil condition according to TSC 2007 and two different earthquakes spectral accelerations on soft soil conditions.

\section{Results of Dynamic Analysis}

Minaret models, bare (unreinforced) and reinforced with FRCM, were subjected to seismic loads by using linear elastic time history analysis for two different artificial accelerograms. Due to the symmetry of the minaret, accelerations were applied in one direction by using only first 20 seconds of artificially generated accelerograms. Modal damping value was assumed as 5\% (critical) for all modes (Figures 8 and 9).

Calculated maximum lateral displacement at the top of the minaret, by utilising the time history analyses, was shown in Table 4. The deflected shape of the minaret shows flexure
TABLE 4: Maximum lateral displacements of top of minaret according to time history analyses before and after seismic retrofit.

\begin{tabular}{lcc}
\hline $\begin{array}{l}\text { Calculated maximum lateral } \\
\text { top displacement }(\mathrm{m})\end{array}$ & $\begin{array}{c}\text { Duzce } \\
\text { EQ@DUZCE }\end{array}$ & Synthetic EQ \\
\hline $\begin{array}{l}\text { Model before seismic } \\
\text { strengthening }\end{array}$ & 0.49 & 0.47 \\
$\begin{array}{l}\text { Model after strengthened with } \\
\text { FRCM }\end{array}$ & 0.30 & 0.33 \\
\hline
\end{tabular}

dominated lateral deformation with the largest displacement calculated at the roof. Roof height of the minaret was taken as $31.25 \mathrm{~m}$ without considering wooden cap. Although the minaret acts as cantilever structure, the deformation is smaller over the height of relatively stiff $4.25 \mathrm{~m}$ high base or boot. The displacement starts to increase above the transition segment at about $5.25 \mathrm{~m}$. Figures 11 and 12 show the lateral deflection of the bare and strengthened minaret models for Duzce and Synthetic records.

Neither Turkish seismic code nor the other existing seismic codes contain any instructions directly related for the assessment/retrofit of slender tower structures made of block stone masonry. Maximum roof drift index of minaret model before retrofit $(\delta / \mathrm{h})$ is calculated as 0.015 for both accelerograms where it reduced to 0.01 for the strengthened models which seems acceptable limit according to FEMA 356 which proposes $1 \%$ performance drift limit collapse prevention for unreinforced masonry walls (for the walls made of hollow or solid brick clay/concrete units) [34].

For the minaret case mentioned in this study, highest maximum principal stress and highest minimum principal stress distributions (occurred at different time intervals) are given in Figures 13, 14, 15, and 16. In Figures 13 and 14, artificial Synthetic EQ accelerogram was used as input, and substantial reduction can be realized for the maximum 


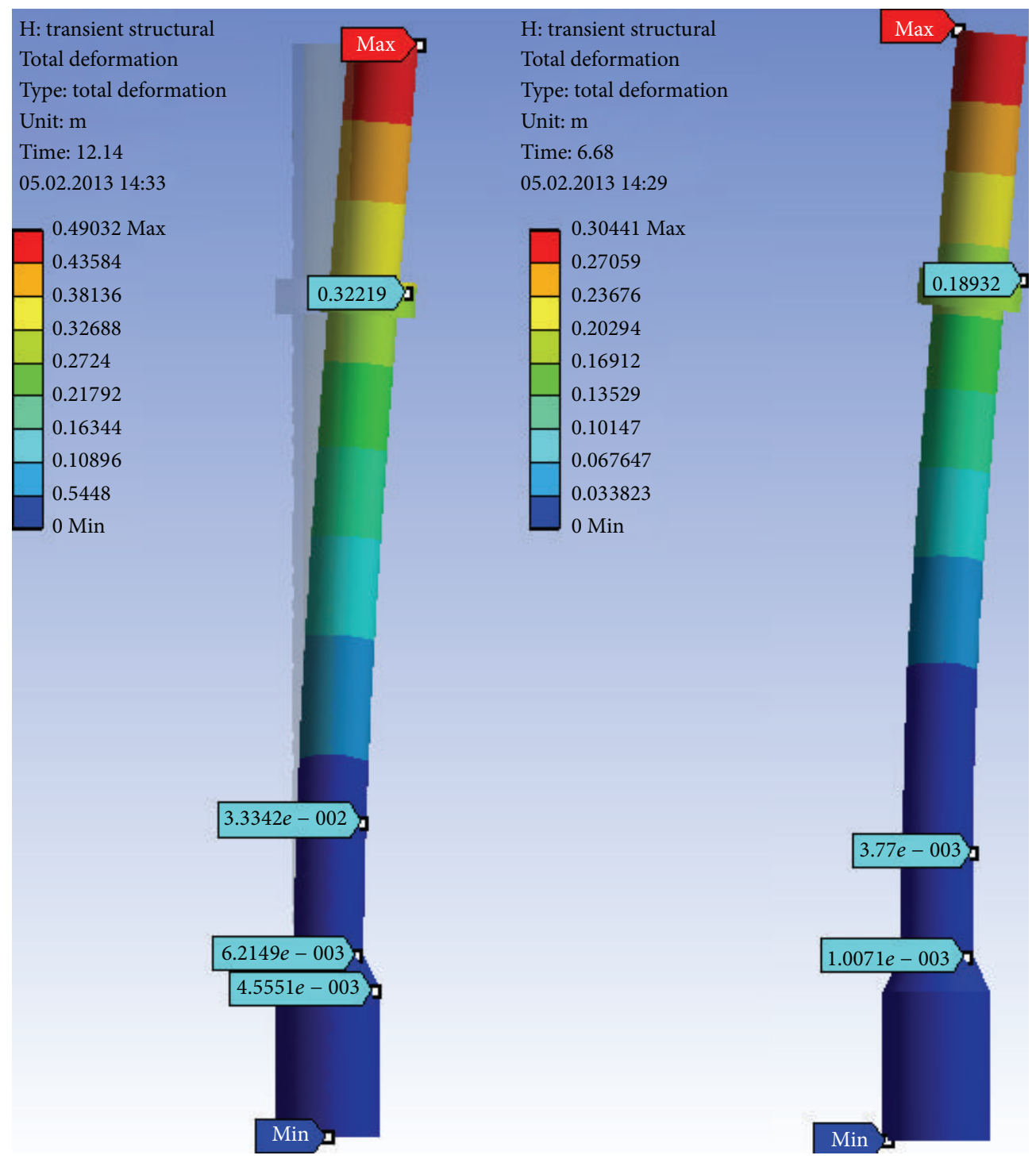

FIGURE 11: Maximum lateral deformation profiles for scaled Duzce EQ record (left: bare minaret model; right: strengthened model, in m).

and minimum principal stresses obtained after the time history analysis by using artificial Synthetic earthquake. The maximum tensile stress on the masonry material raised up to $22 \mathrm{MPa}$ which is much higher than the tensile capacity whereas the compressive stresses exceeded $23 \mathrm{MPa}$ which is almost 2 times higher than compressive strength capacity. It is obvious that the maximum and minimum stress distribution in the Figure 13 shows a possible failure/total collapse of the bare minaret. For the strengthened model, Figure 14, the highest stresses, occurred on bare minaret model seem to be reduced to 4 (tensile) and $10 \mathrm{MPa}$ (compressive), respectively, for the unconfined masonry cross-sections. At the same time, FRCM material practices maximum tensile stress of $154 \mathrm{MPa}$ which is small when compared to its high tensile strength. It can be seen obviously from Figure 14 that FRCM material seems efficient while carrying the tensile stresses particularly over the tensile capacity of the masonry material which is around 1.2 $\mathrm{MPa}$ [3]. The aforementioned tensile stress value seems higher than the limiting tensile strength of the material for unconfined cross-sections. Under such a big event with PGA of $0.6 \mathrm{~g}$ by aiming the collapse prevention performance level, nonlinear character of the material should be taken into account. Typical uniaxial stress-strain curve of masonry materials has a nonlinear character with a descending portion after peak maximum stress attained. The descending portion is significant and reflects a very important property of the masonry material. For an unconfined cross-section, maximum stress capacity is reached at a compressive strain of mostly greater than 0.002 , and beyond this point, strain increase is accomplished with decreasing stress in descending portion of the curve. The descending portion enables material to unload under increasing strains. Due to this property of the stress-strain diagram, a section subjected to bending does not fail when the extreme fiber reaches the maximum tensile stress because at this stage the strain is still less than the failure strain. To verify the potential failure of the 


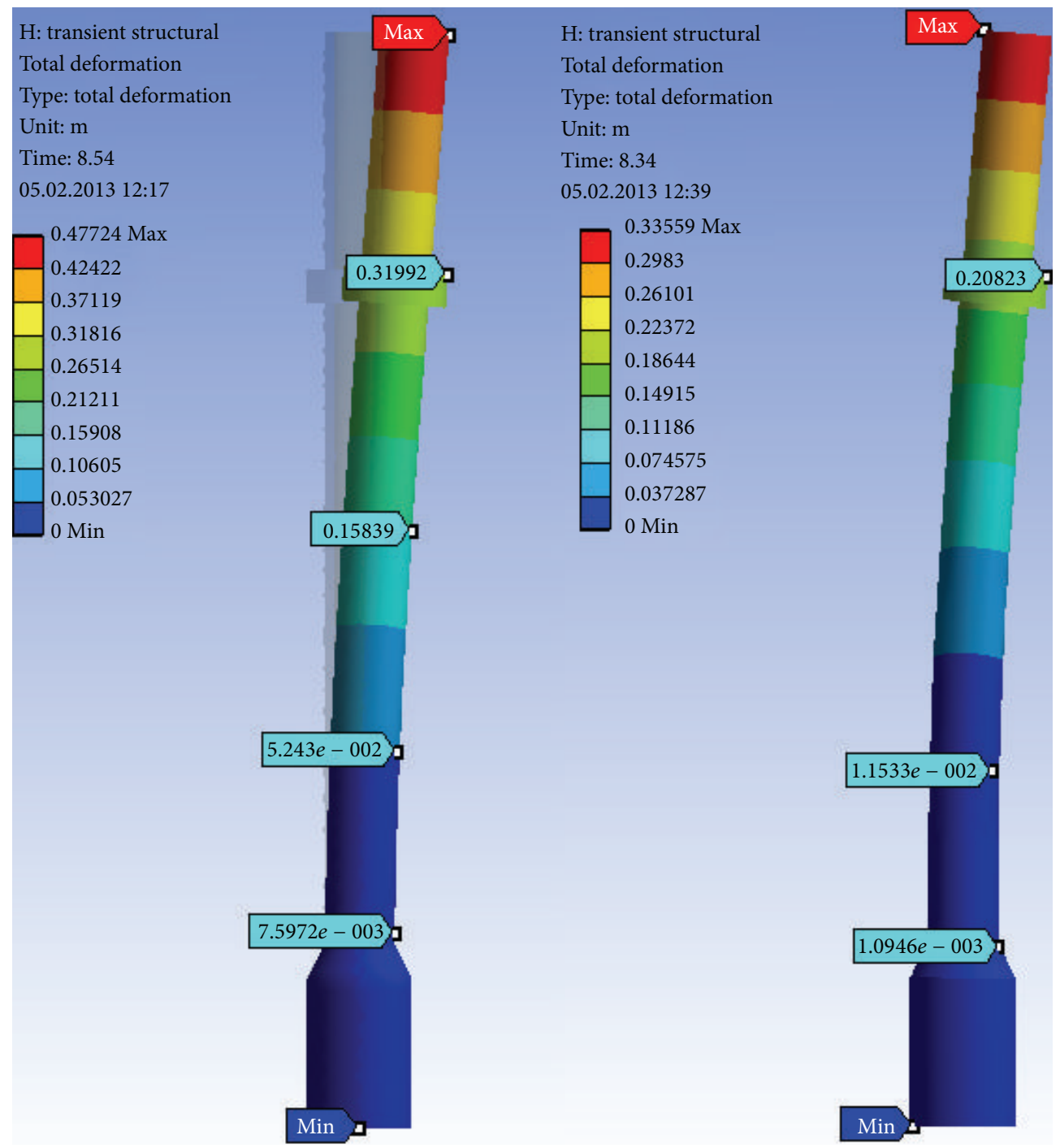

FIGURE 12: Maximum lateral deformation profiles for scaled Synthetic EQ record (left: bare minaret model; right: strengthened model, in m).

minaret, maximum principal elastic strain diagram is given in Figure 14, and it can be seen that maximum compressive strains fall below 0.002 for unconfined masonry sections.

In Figure 15, the highest tensile stress obtained for the model subjected to artificial Duzce accelerogram was over 23.4 MPa for the masonry which is quite high when compared to limited tensile strength. For the strengthened model, Figure 16, these higher tensile stresses reduced to $4.5 \mathrm{MPa}$ right above the cut-off point of the FRCM wrapping due to the abrupt transition of tensile stress between masonry and cover material. In the same figure, maximum elastic strain of unconfined masonry section above cut-off point of FRCM wrapping was much below maximum compressive strain of masonry material. Evaluating the linear stress distribution shows the critical zones which may cause potential failure. It is an undeniable fact that, masonry has nonlinear material properties and evaluating the stress values obtained from linear elastic analysis without considering strains may end misjudgement about failure, especially for collapse prevention performance target. For a particular elastic analysis for brittle materials, maximum compressive strains should be accounted in order to check the safety of cross section.

In order to overcome this problem, a detailed nonlinear analysis should be performed by using nonlinear material properties for masonry. High tensile stresses occurred especially lower regions causes the unreinforced minaret becomes unsafe against seismic loadings. In addition, in terms of roof drift, obtained value of 0.015 (480 $\mathrm{mm}$ roof displacement) seems higher for such masonry slender structures. Under these circumstances, such historical heritages appear vulnerable against strong earthquakes. On the other hand, the complex behaviour of the stone material and the interface mechanics between stones may create another source of weakness. Furthermore, the conservation of historical heritages without any change on the external view should be 


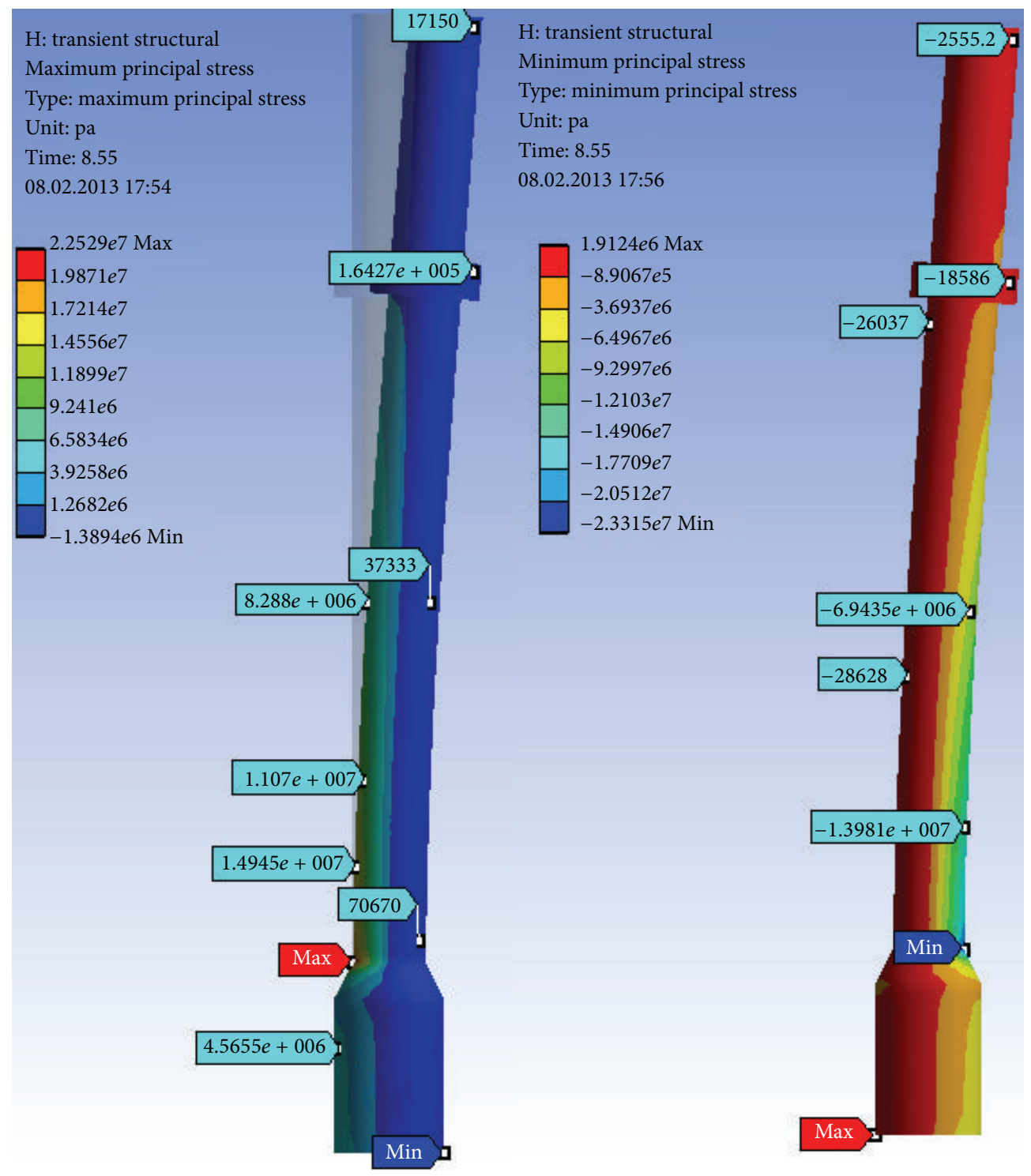

FIGURE 13: Maximum and minimum principal stress distribution for bare minaret model under the effect of scaled synthetic accelerogram (in $\mathrm{Pa}$ ).

taken into consideration while thinking about such structural intervention.

\section{Conclusions}

The paper reports the likely failure mode for a typical existing historic minaret structure located in Istanbul, Turkey. The results obtained from the ambient vibration and material tests and modal analysis have shown that the behaviour under seismic action can be predicted with reasonable results and can be used effectively in the assessment of these minarets to assure their stability in case of a code earthquake (10\% probability of exceedance in 50 years with 475 years return period, strong earthquake) by reinforcing the weakest zones which will undergo the greatest damage (located at the base and the lower part of the minaret). By calibrating the modulus of elasticity of the masonry material, two linear finite element models of the minarets were constructed and analysis results showed the similarity between obtained first period and the one obtained from in situ test for bare minaret. After modal analysis, artificially generated and scaled two ground motion records were used in the time history analysis. The results of two analysis are not much different from each other while comparing maximum stresses, locations of maximum stresses, and maximum deformations. For bare minaret model, compressive and tensile strength capacities are exceeded definitely. That means that under the effect of such probable (above $0.6 \mathrm{~g}$ PGA) earthquakes with a considerable chance of occurring for the following 30 years near Istanbul, very likely stresses may affect the lower part of minarets and may cause the total failure.

In order to eliminate such high risks for existing historical minarets, the deficiency of masonry material under tensile stresses may be compensated by confining the masonry with 


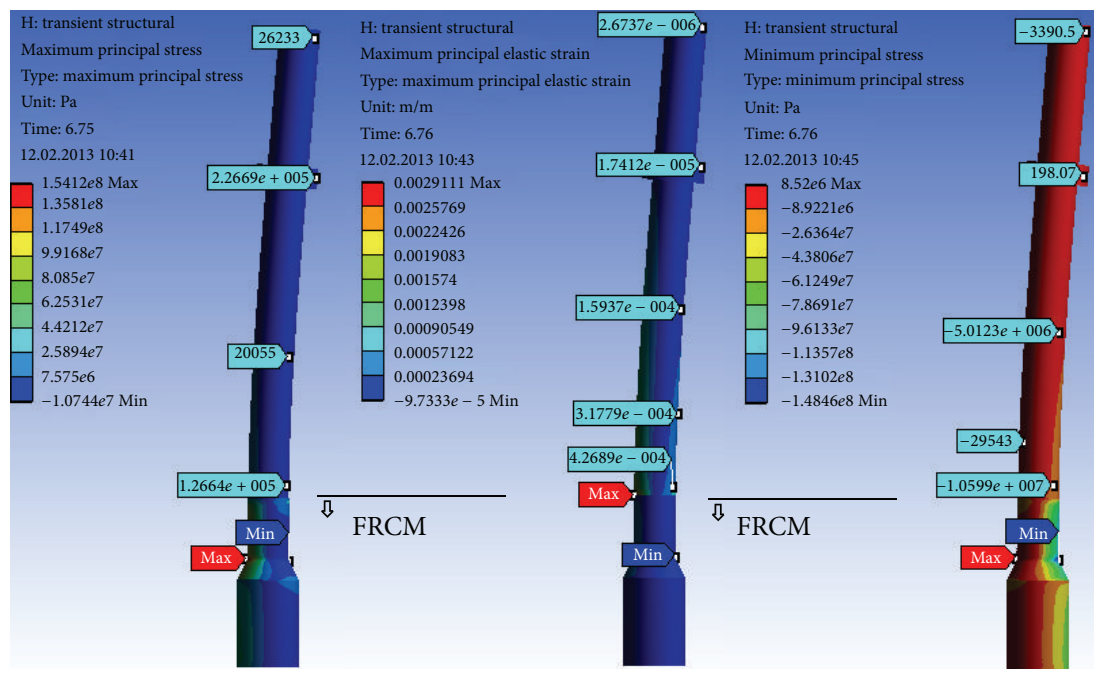

FIGURE 14: Maximum principal stress, maximum principal strain and minimum principal stress distribution for strengthened model under the effect of scaled synthetic accelerogram (in Pa).

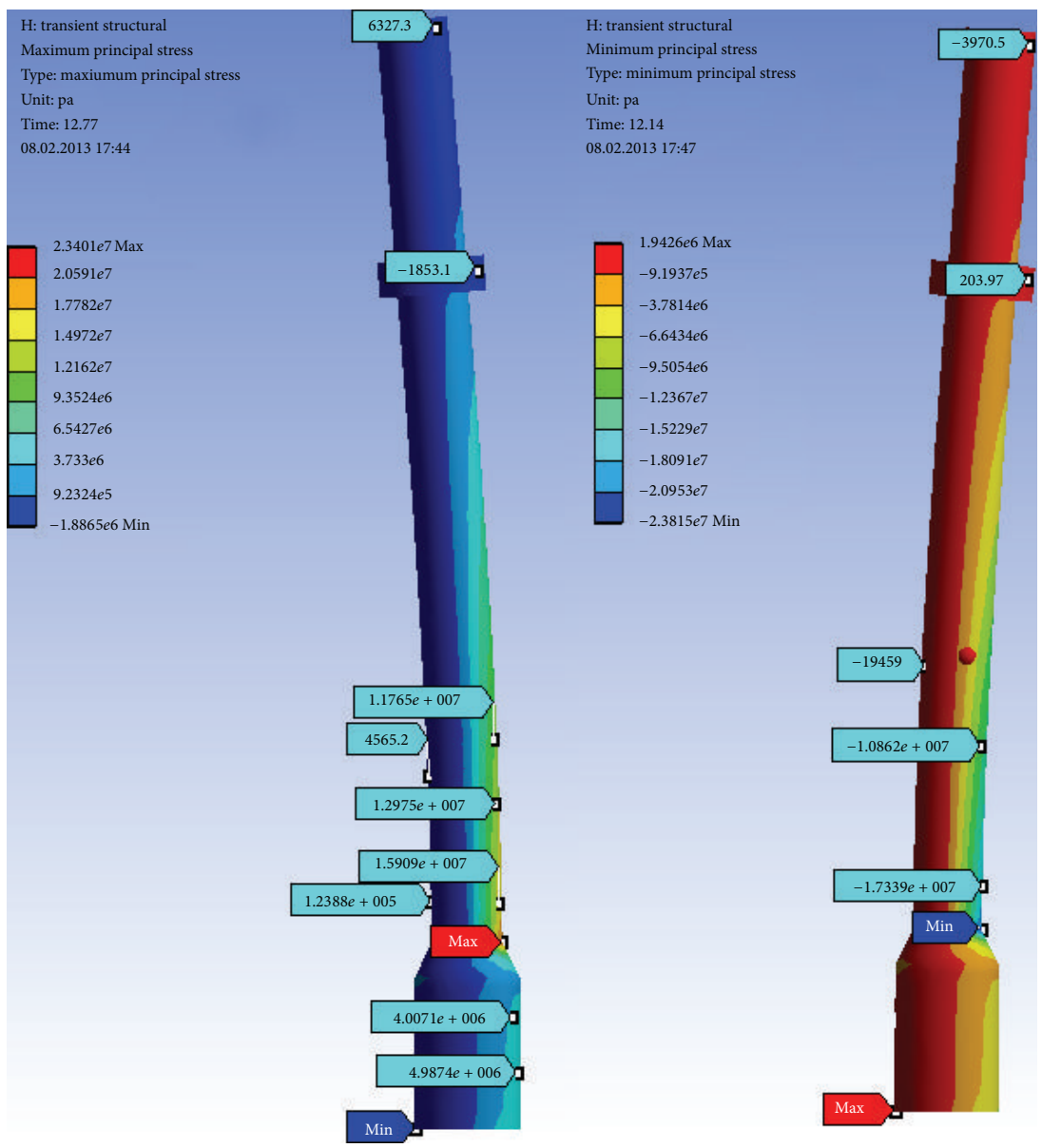

FIGURE 15: Maximum and minimum principal stress distribution for bare minaret model under the effect of scaled Duzce record (in Pa). 


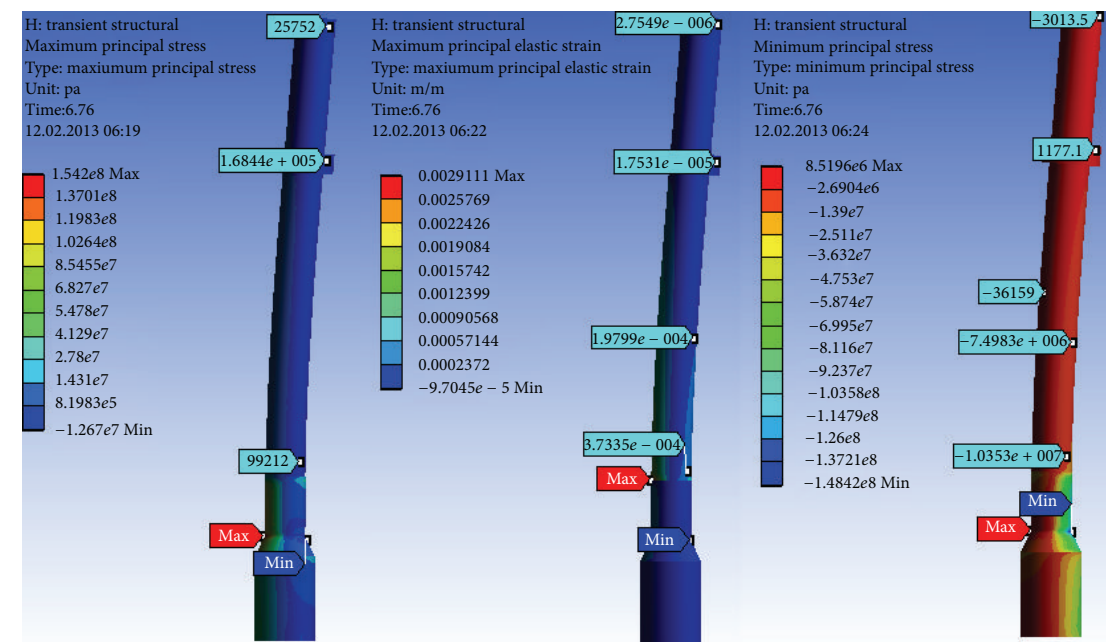

FIGURE 16: Maximum principal stress, maximum principal stain and minimum principal stress distribution for strengthened minaret under the effect of scaled Duzce record (in Pa).

high tensile strength capacity materials bonded to masonry. Due to the circular cross-section of minarets, the application of fiber reinforced cover/wrap seems always practical. Despite extensive use of FRP confinement for such structures, possible use of FRCM material may have many advantages as mentioned before.

The 3D time history analyses performed allow differentiating the behaviour of the minaret during a seismic shaking, including the failure mode and the possible failure zones. When FRCM wrapped around the critical cross-sections, it improves the lateral behaviour and the results are promising in terms of seismic protection of these and similar heritages.

For further research, mosque-minaret structural interaction, soil-structure interaction and de-bonding characteristics of FRCM material should be investigated by utilizing nonlinear models representing the real behavior of masonry under dynamic loading. For some typical historical minaret structures, permanent seismic instrumentation should be installed in order to understand the real behaviour under seismic loading.

\section{Conflict of Interests}

The author does not have any possible conflict of interests with any of the mentioned trademarks.

\section{References}

[1] A. Batur, "1894 Yazı Pek Heyecanlı Geçmişti, Bir Depremin Yüzyıl Dönümü,” Istanbul Dergisi, vol. 10, pp. 25-32, 1994 (Turkish).

[2] K. H. Kuşüzümü, "Istanbul Minareleri, Vakıf Restorasyon Y1llıg1, Sayı, vol. 1, pp. 54-64, 2010 (Turkish).

[3] M. Oguzmert, Yigma Minarelerin Dinamik Davranisi [M.S. thesis], Istanbul Technical University, 2002.

[4] C. Cosgun, Silindirik Yigma Yapilarin Lif Takviyeli Polimer ile Takviye Edilmesi [M.S. thesis], Istanbul Kultur University, 2005.
[5] A. M. Turk and C. Cosgun, "The determination of seismic behaviour and retrofit of historical masonry minaret with FRP," in Proceedings of the 8th International Masonry Conference, vol. 148, pp. 2029-2038, Dresden, Germany, 2010.

[6] A. M. Turk and C. Cosgun, "Seismic behaviour and retrofit of historic masonry minaret," Gradevinar, vol. 64, no. 1, pp. 39-45, 2012.

[7] H. Sezen, G. Y. Firat, and M. A. Sozen, "Investigation of the performance of monumental structures during the 1999 Kocaeli and Duzce earthquakes," in Proceedings of the 5th National Conference on Earthquake Engineering, AE-020, Istanbul, Turkey, 2003.

[8] H. Sezen, R. Acar, A. Dogangun, and R. Livaoglu, "Dynamic analysis and seismic performance of reinforced concrete minarets," Engineering Structures, vol. 30, no. 8, pp. 2253-2264, 2008.

[9] H. Sezen and A. Dogangun, "Seismic performance of historical and monumental structures," in Earthquake Engineering, $\mathrm{H}$. Sezen, Ed., InTech, 2012.

[10] A. Dogangun, R. Acar, H. Sezen, and R. Livaoglu, "Investigation of dynamic response of masonry minaret structures," Bulletin of Earthquake Engineering, vol. 6, no. 3, pp. 505-517, 2008.

[11] A. Dogangun and H. Sezen, "Seismic vulnerability and preservation of historical masonry monumental structures," Earthquake and Structures, vol. 3, no. 1, pp. 83-95, 2012.

[12] A. C. Altunişik, "Dynamic response of masonry minarets strengthened with fiber reinforced polymer (FRP) composites," Natural Hazards and Earth System Science, vol. 11, no. 7, pp. 20112019, 2011.

[13] C. S. Oliveira, E. Çakti, D. Stengel, and M. Branco, "Minaret behavior under earthquake loading: the case of historical Istanbul," Earthquake Engineering and Structural Dynamics, vol. 41, no. 1, pp. 19-39, 2012.

[14] P. B. Lourenço, "Recommendations for restoration of ancient buildings and the survival of a masonry chimney," Construction and Building Materials, vol. 20, no. 4, pp. 239-251, 2006.

[15] P. B. Lourenço, D. V. Oliveira, P. Roca, and A. Orduña, "Dry joint stone masonry walls subjected to in-plane combined loading," Journal of Structural Engineering, vol. 131, no. 11, pp. 1665-1673, 2005. 
[16] P. Gülkan and S. T. Wasti, "Seismic assessment and rehabilitation of historic structures," Structural Longevity, vol. 1, no. 2, pp. 111-134, 2009.

[17] G. J. Fallis, "Innovation for renovation," Concrete International, vol. 31, no. 4, pp. 62-64, 2009.

[18] A. Nanni, "A new tool for concrete and masonry repair, strengthening with fiber-reinforced cementitious matrix composites," Concrete International, vol. 34, no. 4, pp. 43-49, 2012.

[19] http://www.ruredil.it/.

[20] A. D’Ambrisi, L. Feo, and F. Focacci, "Experimental analysis on bond between PBO-FRCM strengthening materials and concrete," Composites B, vol. 44, no. 1, pp. 524-532, 2013.

[21] N. Arioglu and E. Arioglu, Mimar Sinan'in Sectigi Tas: Kufeki ve Cekme Dayanımı, 14, Turkiye Insaat Muhendisligi Teknik Kongresi, Izmir, Turkey, 1997 (Turkish).

[22] K. Erguvanli and Z. Ahunbay, "Mimar Sinan Istanbul'daki Eserlerinde Kullandigi Taslarin Muhendislik Jeolojisi ve Mimari Ozellikleri," Muhendislik Jeolojisi Bulteni, vol. 11, pp. 109-114, 1989 (Turkish).

[23] Z. Ahunbay, Mimar Sinan Yapilarinda Kullanılan Yapım Teknikleri ve Malzeme, Mimarbası Kocasinan Yasadıgı Cag ve Eserleri, Istanbul, Turkey, 1988 (Turkish).

[24] E. Arioglu and N. Arioglu, "Mimar Sinan'ın Taşıyıcı Olarak Kullandığı Kufeki Tasinin Muhendislik Gizemi," in Mimar Sinan Donemi Yapi Etkinlikleri Sempozyumu, Istanbul,Turkey, 1999 (Turkish).

[25] ANSYS V14. 0. 0, Swanson Analysis System, Canonsburg, Pa, USA, 2011.

[26] TSC, Specification for Buildings to Be Built in Disaster Areas, Ministry of Public Works and Settlement, 2007.

[27] Eurocode 8, Design of Structures for Earthquake Resistance, 1998.

[28] D. Rivera, R. Meli, R. Sánchez, and B. Orozco, "Evaluation of the measured seismic response of the Mexico City Cathedral," Earthquake Engineering and Structural Dynamics, vol. 37, no. 10, pp. 1249-1268, 2008.

[29] SeismoArtif, Seismosoft Ltd., 2012.

[30] http://peer.berkeley.edu/products/strong_ground_motion_db .html.

[31] Kiyi ve Liman Yapilari, Demiryollari, Hava Meydanlari Inşaatlarina İlişkin Deprem Teknik Yonetmeligi, Resmi Gazete 26617, 2007 (Turkish).

[32] http://www.koeri.boun.edu.tr/depremmuh/yonetmelikler/PGA_ 475_Contour.kmz.

[33] Google Earth, Google 7. 0. 3. 8542, 2013.

[34] FEMA-356, Prestandard and Commentary for the Seismic Rehabilitation of Buildings, FEMA Federal Emergency Management Agency, Washington, DC, USA, 2000. 

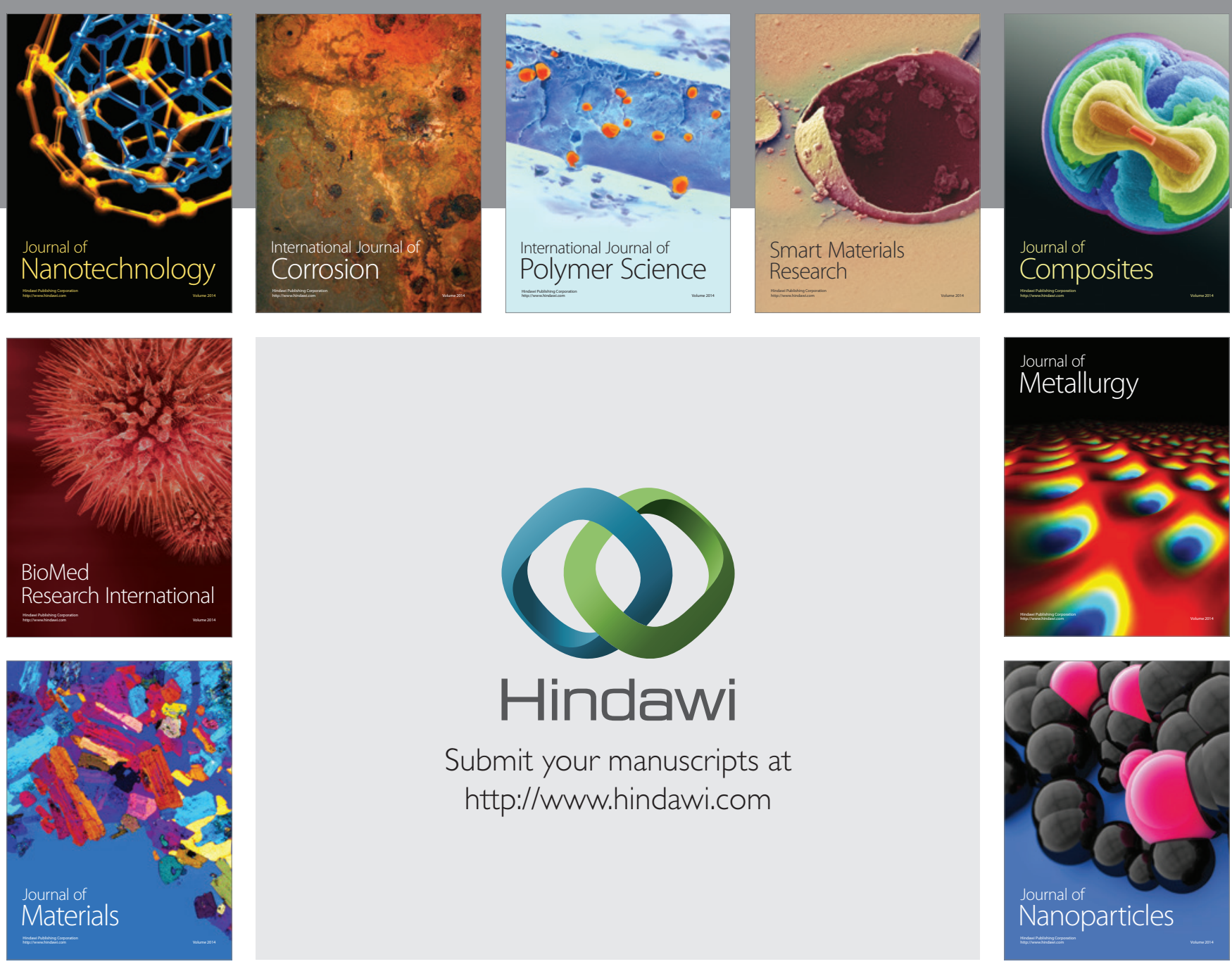

Submit your manuscripts at http://www.hindawi.com
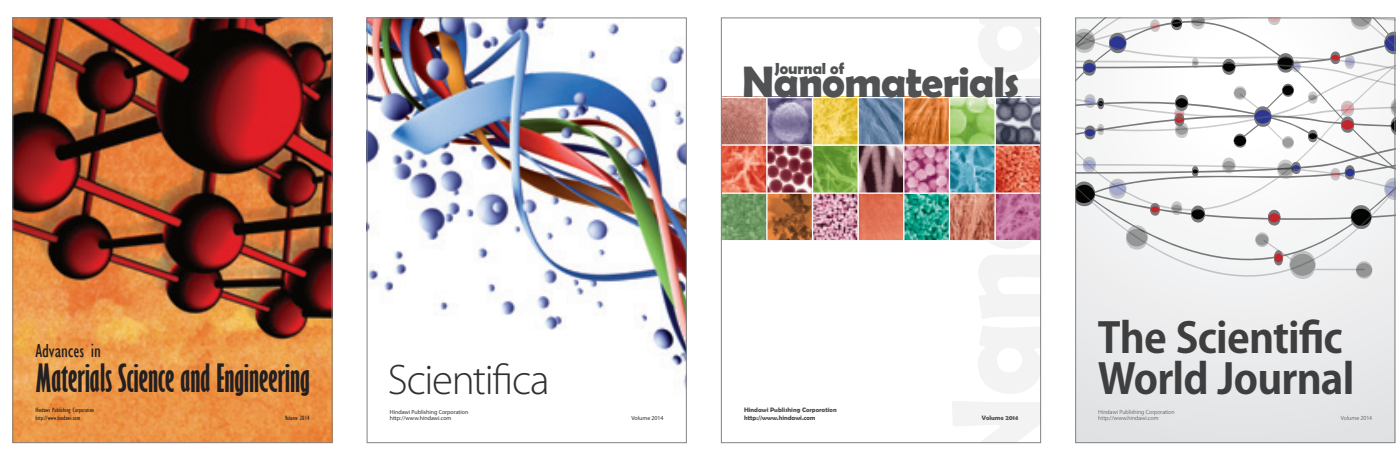

\section{The Scientific World Journal}
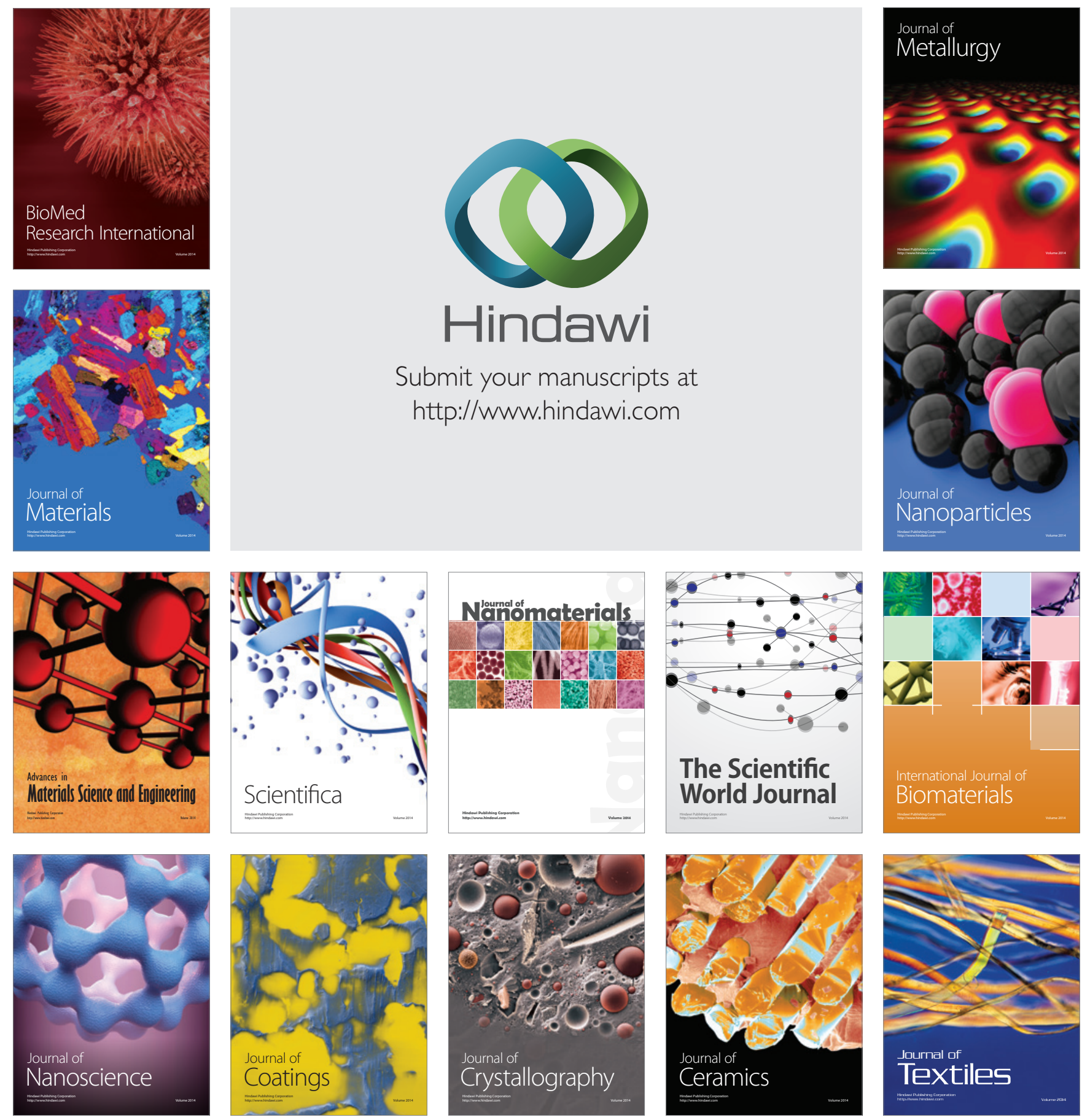